\title{
FROM STATE SECURITY TO HUMAN SECURITY: WITH SPECIAL REFERENCE TO STATUS OF TEA GARDEN WOMEN WORKERS OF JORHAT DISTRICT.
}

\author{
Silpika Dutta \\ Dibrugarh University, Assam, India
}

\begin{abstract}
Health is the basic requirement for fulfillment of all human aspiration. Health refers to a state of complete Physical, mental and social wellbeing. Health security, as discuss in the earlier chapter refers to minimum protection from diseases and unhealthy lifestyles. Health security now regard as a major component of Human security. Human Security is not (only) a concern with weapons. It is a concern with human dignity. In the last analysis, it is child who did not die, a disease that did not spread an ethnic tension that did not explode, a dissident who was not silenced, a human spirit that was not crushed.
\end{abstract}

Key words: State Security, Human Security, tea garden, Jorhat district, women workers

Cite this Article: Silpika Dutta, From State Security to Human Security: with Special reference to Status of Tea Garden Women Workers of Jorhat district, International Journal of Management, 11(12), 2020, pp. 1543-1548.

http://iaeme.com/Home/issue/IJM?Volume $=11 \&$ Issue $=12$

\section{INTRODUCTION}

The meaning of human security is not similar with that of traditional notion of security. The Concept of "Security" can be traced back to the end of cold war. At that time security is understand in terms of nation's security. A nation's security has always depended on the type and level ofmilitary technology existing at a given time. Since human communities first came into contact with each other, security has been the chief interest of rulers and remains the overall prime national interest. Governments go to great lengths to protect their people and to preserve their territories and themselves. Security is closely related to sovereignty which means keeping the state whole: its government, its people, and its territory. Thus, the term 'security' refers absence of threats. From the traditional security the concept of human security is arise as an emerging paradigm for understand. 
The concept of human security was for the first time expressed in the words of Mahbub U1 Haq Human Security is not (only)a concern with weapons. It is a concern with human dignity. In the last analysis, it is child who did not die, a disease that did not spread an ethnic tension that did not explode, a dissident who was not silenced, a human spirit that was not crushed. Human Security brings together concerns related to peace, security and human development'. Human Security holds a people centered view of security. It can be defined as freedom from want, freedom from fear and food security. The Commission for Human Security (CHS) defined Human Security as Protecting fundamental freedoms- freedoms that are the essence of life. It means protecting people from critical (severe) and pervasive (widespread) threats and situations. It means using processes that build on people's strengths and aspiration. It means creating political, social, environmental, economic, military and cultural systems that together give people the building blocks of survival, livelihood and dignity. Thus, while traditional school of security concerns with the power and weapons of the state, human security addressed ecological, environment and economic security matters. Human Security defines the human being as the new security referent. In this paper an attempt has been made study the health security of the tea garden women workers of Jorhat district only.

\section{OBJECTIVES OF THE STUDY}

To examine the various programmes and human security measures of Plantation Labor Rules, 1956 adopted by the government to improve the condition of tea garden workers, particularly women workers.

The present study attempts to know their working conditions and condition of along with studying the effects on their health which is directly related to the health security of the tea garden workers.

To highlight the importance of appropriate policy intervention for provide the human security specially health security in real sense.

\section{SIGNIFICANCE OF THE STUDY}

Health is the basic requirement for the enjoyment of better quality life. The health status of the tea garden workers in Assam is comparatively very low. Among the tea garden workers the health condition of women folk are more degradable. Therefore, one arena of human security that is health security is selected to study.

\section{HYPOTHESIS:}

The level of human security among tea garden workers of Assam is relatively low. Especially, the health security of the women tea garden workers is relatively poor as compared to the state average and national average due to lacuna in proper implementation of policies for this category of people.

\section{METHODOLOGY}

In this study it was proposed to study the pattern of tea garden labour and provision human security specially health security, it was considered scientific to be carry out the study on a sufficiently large sample to provide a reliable data. The total sample consists of 200 workers in which 100 will be women working in tea garden, in which 100 will be men workers Both men and women are selected to make a comparison of heath security among tea garden workers. The study has been conducted in the following two tea estates of Jorhat district. 


\subsection{Government of Assam undertaking Tea Estate}

Cinnamora Tea Estate, Jorhat

\subsection{Private Sector Tea Estate}

LohpohiaTea Estate, Jorhat.Cinnamora Tea Estate is undertaken by government of Assam (under ATC) and Lohpohia Tea estate is undertaken by private company. These tea garden are selected to make a comparative study.

\section{FINDINGS AND DISCUSSION}

\subsection{Provisions provided as per the Assam Plantation Labour Rules, 1956 in both the tea Estates}

Table 1 Facilities provided to the Tea Garden Workers

\begin{tabular}{|c|c|c|c|}
\hline SI No & Facilities Provided to the Workers & Cinnamara T. E & Lohpohia Tea Estate \\
\hline 1. & Hospital Facilities & Yes & Yes \\
\hline 2 & Housing Facilities & Yes & Yes \\
\hline 3 & Sanitary Facilities & Yes & Yes \\
\hline 4 & Educational Facilities & Yes & Yes \\
\hline 5 & Drinking Water Facilities & Yes & Yes \\
\hline 6 & Creches for children Facilities & Yes & Yes \\
\hline 7 & Recreational Facilities & & Pes \\
\hline
\end{tabular}

Table 1. shows both the tea estates follows the Plantation Labour Rules and provides above mention facilities to its workers. Here, an comparative analysis of the health facilities of the tea estates are provided by the researchers which is purely based on observation and interaction with the tea garden workers. Hospital facilities: As per the Rules 35 of the Assam Plantation Labour Rules, 1956 as prescribed under section 10 of the Plantation Labour Act, 1951 both the tea garden provides hospitals for the workers.

Table 2 Present Status of Health Service Facilities in Sample Tea Garden (Management Wise)

\begin{tabular}{|c|c|c|c|}
\hline SI No & $\begin{array}{c}\text { Parameter of Health } \\
\text { facilities }\end{array}$ & $\begin{array}{c}\text { Cinnamara tea estate (in } \\
\text { number) }\end{array}$ & $\begin{array}{c}\text { Lohpohia tea } \\
\text { Estate(innumber) }\end{array}$ \\
\hline 1 & hospital & 1 & 1 \\
\hline 2 & No of whole time doctor & 4 & 2 ANMS \\
\hline 3 & No of trained nurse & 4 & 1 \\
\hline 4 & No of whole time pharmacist & & 1 \\
\hline 5 & No of health Assistant & & \\
\hline 6 & No of midwives & & \\
\hline 7 & No of ambulance service & & \\
\hline 8. & Family planning programme & & \\
\hline 9. & No of dispensaries with child & & \\
\hline & Immunization & & \\
\hline
\end{tabular}


From State Security to Human Security: with special reference to status of tea garden women workers of Jorhat district

\begin{tabular}{|c|c|c|c|}
\hline 10 & Free medicine & $\begin{array}{c}\text { Yes. Supplied by NRHM } \\
\text { for common diseases }\end{array}$ & $\begin{array}{c}\text { Yes. Supplied by } \\
\text { NRHM for common } \\
\text { diseases }\end{array}$ \\
\hline 11 & Sweeper & & 1 \\
\hline
\end{tabular}

\subsection{Common Diseases of The Tea Garden Workers of Surveyed Tea Estates}

Let, Sample for Diseases Cold and Fever, Gastroenteritis and other bowel diseases, Anemia, Diarrhea, Eye Diseases $=($ men + women $)=(100+100)=200 \%$

Let, Sample for Diseases Cold and Fever, Gastroenteritis and other bowel diseases, Anemia, Diarrhea, Eye Diseases $=($ men + women $)=(100+100)=200 \%$

Table 3 Age and Sex Wise Distribution of Diseases among sample the Tea Garden Workers

\begin{tabular}{|c|c|c|c|c|c|}
\hline $\begin{array}{l}\text { Sl } \\
\text { no }\end{array}$ & Diseases & $\begin{array}{l}\text { Age } \\
\text { Group }\end{array}$ & Man & Women & $\begin{array}{c}\text { \% for both men and } \\
\text { women }\end{array}$ \\
\hline \multirow[t]{4}{*}{1} & \multirow{4}{*}{$\begin{array}{l}\text { Cold and } \\
\text { Fever }\end{array}$} & $20-30$ & 30 & 30 & 30 \\
\hline & & $30-40$ & 30 & 40 & 35 \\
\hline & & $40-50$ & 20 & 15 & 17.5 \\
\hline & & $50-60$ & 20 & 15 & 17.5 \\
\hline \multirow[t]{4}{*}{2} & \multirow{4}{*}{$\begin{array}{c}\text { Gastroenteritis and other } \\
\text { bowel } \\
\text { diseases }\end{array}$} & $20-30$ & 35 & 25 & 30 \\
\hline & & $30-40$ & 25 & 35 & 30 \\
\hline & & $40-50$ & 20 & 20 & 20 \\
\hline & & $50-60$ & 20 & 20 & 20 \\
\hline \multirow[t]{4}{*}{3} & \multirow[t]{4}{*}{ Anemia } & $20-30$ & 30 & 30 & 30 \\
\hline & & $30-40$ & 30 & 40 & 30 \\
\hline & & $40-50$ & 20 & 15 & 17.5 \\
\hline & & $50-60$ & 20 & 15 & 17.5 \\
\hline \multirow[t]{4}{*}{6} & \multirow[t]{4}{*}{ Diarrhea } & $20-30$ & 30 & 30 & 30 \\
\hline & & $30-40$ & 30 & 40 & 35 \\
\hline & & $40-50$ & 20 & 15 & 17.5 \\
\hline & & $50-60$ & 20 & 15 & 17.5 \\
\hline \multirow[t]{4}{*}{8} & \multirow[t]{4}{*}{ Eye Diseases } & $20-30$ & 30 & 30 & 30 \\
\hline & & $30-40$ & 30 & 40 & 35 \\
\hline & & $40-50$ & 20 & 15 & 17.5 \\
\hline & & $50-60$ & 20 & 15 & 17.5 \\
\hline \multirow[t]{4}{*}{9} & \multirow[t]{4}{*}{ Respiratory problem } & $20-30$ & - & - & 0 \\
\hline & & $30-40$ & - & - & 0 \\
\hline & & $40-50$ & - & - & 0 \\
\hline & & $50-60$ & - & - & 0 \\
\hline 10 & Ulser & $20-30$ & 30 & 30 & 30 \\
\hline
\end{tabular}




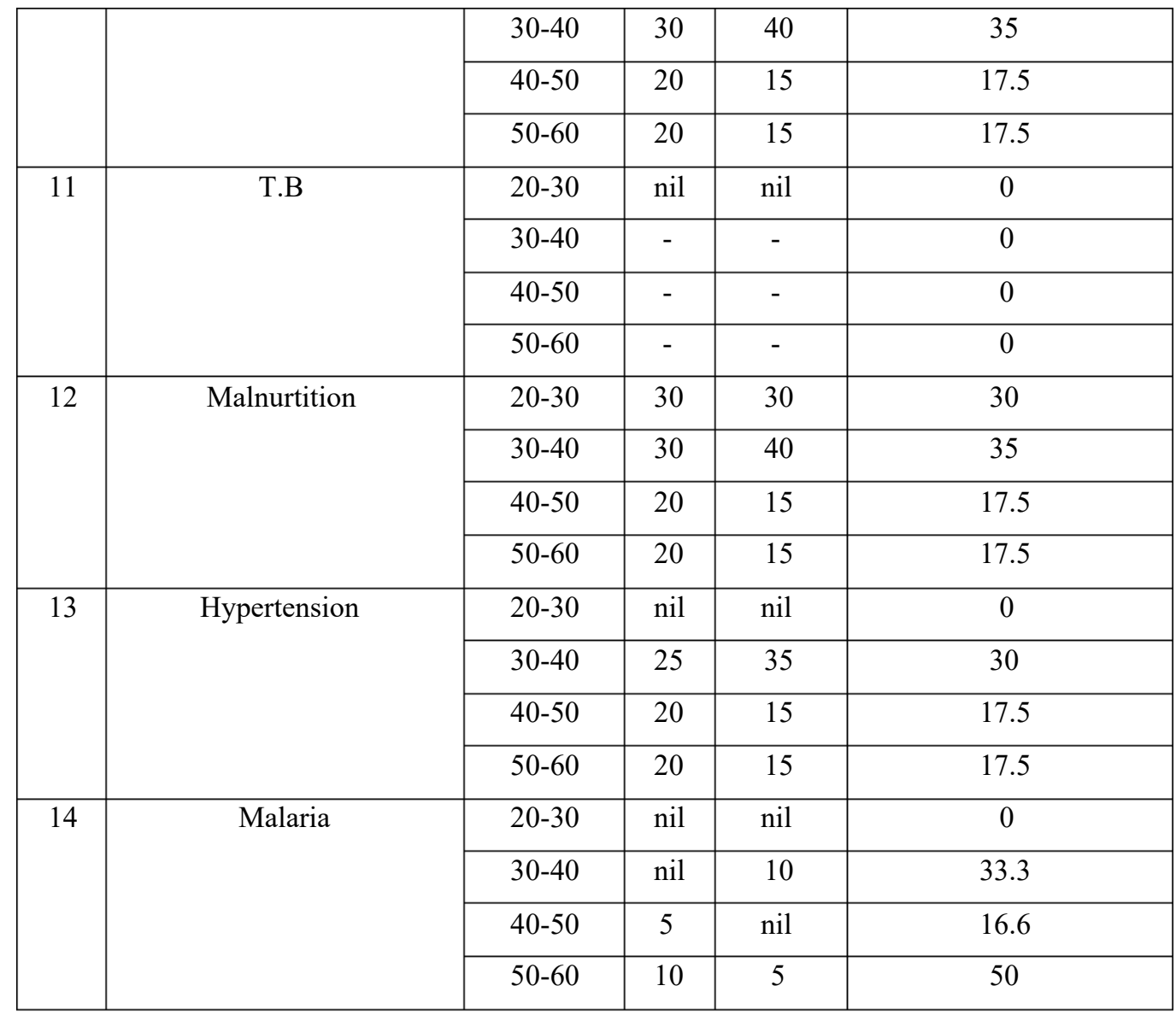

\section{CONCLUSION AND SUMMARY}

Health is the basic requirement for fulfillment of all human aspiration. Health refers to a state of complete Physical, mental and social wellbeing. Health security, as discuss in the earlier chapter refers to minimum protection from diseases and unhealthy lifestyles. Health security now regard as a major component of Human security. In this $21^{\text {st }}$ century, about half of the world population are unable to achieve their full health potential. The poor, marginalized and included have higher risk of dying than other privileged group. These disparities are found not only among the developed and underdeveloped or developing countries, but also within the risk and poor people and men and women of the country itself with regard to women health, it may be noted that along with other factors likes food and drink, personal hygienic and environmental.

In the light of above theoretical perspective of Human Security and Tea Garden Women Workers, in this research work an attempt has been made to examine how various legislation and social security measures adopted for the tea garden workers to provide human security. The tea garden workers constitute a major part of the total work force of Assam. Tea garden women workers also contribute to building up economy and also plays an important role in social and political activities.

But, still the tea garden labour community of Assam recognizes as the most exploited and backward class of people who lives in the interior places and works in the tea garden for livelihood. The poverty, addiction to the people to local beer, poor standard of living, poor education, health and hygiene facilities, lack of political awareness are the malice of their lives which makes them most disadvantaged section of the society. They are exploited socially, economically, politically, culturally and educationally. They engages themselves in plucking of the tea leafs without destroying the quality is a crucial work but provides low wages compare 
From State Security to Human Security: with special reference to status of tea garden women workers of Jorhat district

to the men workers. These women are overburden due to productive and reproductive works, enjoy no time for relaxation. The lag behind man and other women in the societies in every spheres and lives in the discriminatory treatments. Though some human security measures and government programmes are available in the tea garden, still they take no part in decision making process, enjoys low health status and works and lives almost in insecurity atmosphere. It intends to make an in-depth study about the exploiting condition of tea garden women workers due to the cultural social political contexts of gender inequality prevailing in their society.

\section{REFERENCE}

[1] Taylor, Viviene), "From State Security to Human Security and Gender Justice", Agenda: Empowering Women for Gender Equity, No 59, Women in War, p.65, 2004

[2] Coomaraswamy, Radhika, "Human Security and Gender Violence" Economic \& Political Weekly,Vol 40, No 44/45 ,p. 4729, 2005

[3] Anthony,M. Caballero: Revisioning Human Security South EastAsia, AsianPerspective,2004.

[4] Awasthi, R.C: Economics of tea Industry in India with special reference to Assam, United Publishers, Guwahati,1978.

[5] Borah, Dr. Lolit: Asomor Chah Janogusthir Samaj Aru Sanskriti, Koustubh Prakashan, Dibrugarh, 2006

[6] Bhadra, R.K. and Bhadra, Mita: Plantation Labourers of North-East India, N.L. Publishers, Dibrugarh, 1997

[7] Chari,P. R and Gupta, Sonika: Human Security in South Asia- Gender , Energy, migration and Globalisation ,Social Science Press, New Delhi,2003.

[8] Chaturvedi, T. N Administration For Child Welfare. Indian Institute of Public Administration, New Delhi,1979.

[9] Chakravorty, R. N: Socio-Economic Development of Plantation workers in North-East India, N.L. Publishers, Dibrugarh, 1997.

[10] Kapoor, Promila: Empowering the Indian Women. Publication Division, Ministry of Broadcasting, Government of India,2001.

[11] Kumar, R: Child Development in India Health Welfare and Management, Ashish Publishing House, New Delhi, 1988

[12] Kaniampady, E: Status of Women Working in the Tea Plantation,Akansha publishing house, New Delhi,2003.

[13] Khanna, S.K: women and Human Rights, Common Wealth Publishers Pvt. Ltd, New delhi, 2011

[14] Roberts,David.Human Insecurity Global Structures of Violence,ZedBooks,NewYork,2008.

[15] Sen, Amayta: On Economic Inequaltiy, Oxford University Press ,1973.

[16] Saharia, U: Tea Labourers of Assam, Koustubh Prakashan, Dibrugarh, 2005

[17] Singh, D. P: Women Workers in unorganized Sector, Deep and Deep publication, New Delhi,2008. 